九州大学学術情報リポジトリ

Kyushu University Institutional Repository

\title{
Preparation of Liposomes for Disintegration in the Intestinal Environment
}

Yoshimaru, Tetsuro

Laboratory of Food Analysis, Faculty of Agriculture, Kyushu University

Nakayama, Makiko

Laboratory of Food Analysis, Faculty of Agriculture, Kyushu University

Ohmachi, Kazunari

Laboratory of Food Analysis, Faculty of Agriculture, Kyushu University

Matsumoto, Kiyoshi

Laboratory of Food Analysis, Faculty of Agriculture, Kyushu University

https://doi.org/10.5109/24291

出版情報：九州大学大学院農学研究院紀要. 43 (3/4)，pp.441-449，1999-02. Kyushu University バージョン：

権利関係 : 
J. Fac. Agr., Kyushu Univ., $43(3 \cdot 4), 441-449$ (1999)

\title{
Preparation of Liposomes for Disintegration in the Intestinal Environment
}

\author{
Tetsuro Yoshimaru, Makiko Nakayama, Kazunari Ohmachi \\ and Kiyoshi Matsumoto
}

Laboratory of Food Analysis, Facnlly of Agriculture,

Kyushu University, Fukuoka 812-8581, Japan

(Recerined October 28, 1998 and accepted November 6, 1998)

\begin{abstract}
Denazyme AP from Aspergillus oryzae was successfully encapsulated into liposomes by using the reverse:-phase evaporation vesicle method. Liposomes were prepared with a yicld of $52.0 \%$ and a particle diameter of several $\mu \mathrm{m}$. The liposomes were very resistant to digestion in the gastric: environment $(\mathrm{pH}$ 1.2), suggesting that liposome-encapsulation is an effective means for protecting denazyme $\mathrm{AP}^{2}$ against gastric conditions. Further, the efficiency of release was about $80 \%$ within 10 min in a solution of bile salts $(\mathrm{pH} 6.2)$. To increase the quantity of denazyme AP encapsulated by this method, the optimal conditions for liposome-encapsulation were investigated. The encapsulation efficiency was improved by increasing the lecithin concentration in ethanol to $75 \mathrm{mM}$. The ratio of lecithin/denazyme AP also affected the efficiency, giving the highest value at a ratio of 1.0 .
\end{abstract}

\section{INTRODUCTION}

Liposomes provide a good delivery system for therapeutic agents to tissues. In most cases, liposomes are administered systemically via injection. The effectiveness of orally administrating drug-containing liposomes has also been discussed by several researchers, and a decrease in the concentration of blood glucose in diabetic rats that were orally administered insulin entrapped in liposomes has been reported (Patel and Ryman, 1976). Rowland and Woodley (1981) observed that horseradish peroxidase, which is susceptible to degradation in the intestine, was absorbed into the intestinal sacs without degradation when administered in a liposome-entrapped form. These studies suggest that liposome-encapsulation is effective for protecting proteins in the gastrointestinal tract. If materials, such as functional peptides, can be efficiently encapsulated into liposomes by a simple preparation method, they can act more effectively.

In addition, as altempts are made to improve chemotherapy in the whole animal or to modify cellular physiology by introducing regulatory molecules into the cell, the need for liposome preparations that can entrap a large percentage of the aqueous phase has becomc apparent. The original liposome preparations by Bangham et al. (1965), consisting of multilamellar vesicles, have been admirably suited to defining many membrane properties and were the basis for the development of the sonicated unilamellar vesicles. However, both multilamellar and unilamellar vesicles have a relatively low volume of entrapped aqueous space per mole of lipid and have restricted ability to encapsulate macromolecules. Therefore, we have investigated conditions that not only produce a liposome that releases its contents only in the small intestine, and also achieves encapsulation of a large percentage of macromolecules. In this study, denazyme AP from 
Aspergillus oryzae was selected as a model macromolecular inclusion substance for case of cvaluation of resistance and release efficiency of liposomes in a particular environment. We describe the method and characteristics of the liposomes produced by ethanol injection and reverse-phase evaporation vesicle.

\section{MATERIALS AND ME'THODS}

\section{Materials}

Egg lecithin was kindly supplied by Taiyo Kagaku Co. (Mic, Japan). Denazyme AP from Aspergillus oryzae was obtained from Nagase Biochemicals Co. (Kyoto, Japan). The bile salts, glycocholic acid, glycochenodeoxycholic acid, glycodeoxycholic acid, taurocholic acid, taurochenodeoxycholic acid, and taurodeoxycholic acid were purchased as sodium salts from Sigma Chemical Co. (St. Louis, MO, U.S.A.). All other chemicals were obtained from Nacalai Tesque (Kyoto, Japan) and were of analytical reagent grade.

\section{Preparation of liposomes}

To prepare liposomes that dissolve only in the small intestine, we encapsulated denazyme AP from $A$. oryzae by the reverse-phase evaporation vesicle method and the ethanol injection method because of their convenience and non-toxic conditions.

First, liposomes were prepared by the reverse-phase evaporation vesicle (REV) method. One gram of egg lecithin was dissolved in $60 \mathrm{ml}$ of $93 \%$ ethanol $(50 \mathrm{mM}$ lecithin solution), and $10 \mathrm{ml}$ of $0.5 \%$ solution $(\mathrm{w} / \mathrm{v})$ of denazyme AP was added. The resulting two-phase system was sonicated briefly ( $5 \mathrm{~min}$ ) in a bath-type sonicator until the mixture become either a clear one-phase dispersion or a homogeneous opalescent dispersion. The mixture was then placed on a rotary evaporator, and the organic solvent was removed under reduced pressure (water aspirator) at $37^{\circ} \mathrm{C}$. Finally, the liposomes were subjected to freeze--drying.

Another method for the preparation of liposomes that avoids both sonication and detergents is the ethanol injection (EI) method. One gram of egg lecithin was dissolved in $60 \mathrm{ml}$ of $93 \%$ ethanol ( $50 \mathrm{mM}$ lecithin solution), and $5.0 \mathrm{~g}$ of polyethylene glycol (\#6000) and $0.3 \mathrm{ml}$ of soybean oil, to strengthen the lipid membrame, were added. This lecithin solution was injected into $120 \mathrm{ml}$ of a $0.042 \%$ solution $(\mathrm{w} / \mathrm{v})$ of denazyme AP at phase transition temperature $\left(60^{\circ} \mathrm{C}\right)$ with a Hamilton syringe while the denazyme AP solution was rapidly stirred. Stirring of this mixture was continued to remove excess ethanol, and the mixture was then freeze-dried.

\section{Assay of enzymatic activity}

Denazyme AP activity was determined by a spectrophotometric method (Anson, 1938), using a calibration curve for different concentrations of tyrosine solutions (20-80 $\mu \mathrm{g} / 2 \mathrm{ml}$ of $0.2 \mathrm{M} \mathrm{HCl}$ ). For each assay, $1 \mathrm{ml}$ of denazyme AP solution (suitably diluted so that absorbance was in the range of the calibration curve) was incubated with $5 \mathrm{ml}$ of a $0.6 \%$ solution (w/v) of Hammersten-casein (Wako Pure Chemicals Ltd., Osaka, Japan) that had been dissolved in a $0.05 \mathrm{M}$ solution of $\mathrm{Na}_{2} \mathrm{HPO}_{4}\left(\mathrm{pH} \mathrm{7.5)}\right.$ as substrate at $37^{\circ} \mathrm{C}$ for $10 \mathrm{~min}$. The reaction was then stopped by addition of $5 \mathrm{ml}$ of $0.11 \mathrm{M}$ trichloroacetic acid. After incubation at $37^{\circ} \mathrm{C}$ for $30 \mathrm{~min}$, the solution was filtered through filter paper (No. $5 \mathrm{~B}$, 
Advantec Toyo Co, Tokyo, Japan). Five $\mathrm{ml}$ of $0.55 \mathrm{M} \mathrm{Na}_{2} \mathrm{CO}_{3}$ and $1 \mathrm{ml}$ of Folin-Ciocalteu reagent (Nacalai Tesque Co.) were then added to $2 \mathrm{ml}$ of the filtrate, and the absorbance was measured at $660 \mathrm{~nm}$ with a spectrophotometer (UV-1200, Shimadzu Co., Kyolo, Japan). One unit was defined as the enzymatic activity that, under the present assay conditions, liberated Folin-positive amino acids and peptides cquivalent to $1 \mu \mathrm{mol}$ tyrosine in 1 min.

\section{Efficiency of encapsulation of denazyme AP into liposomes}

Before measurement, $50 \mathrm{mg}$ of liposomes was ground by a mortar and a pestle in $1 \mathrm{ml}$ of $0.1 \mathrm{M}$ phosphate buffer $(\mathrm{pH} 7.5)$. A suitable dilution of the resultant solution was assayed for enzymatic activity as described above. The encapsulation efficiency was calculated by expressing the amounts of denazyme AP encapsulated as a percentage of the initial amounts of denazyme $\mathrm{Al}^{3}$ used to prepare the liposomes.

\section{Stability and release efficiency of liposomes}

The stability of liposomes in gastric fluids was investigated. A $100 \mathrm{mg}$ aliquot of the liposomes was incubated at $37^{\circ} \mathrm{C}$ with reciprocal shaking (100 strokes $/ \mathrm{min}$ ) in $10 \mathrm{ml}$ of a solution of $\mathrm{HCl}$ containing $0.2 \% \mathrm{NaCl}(\mathrm{pH} 1.2)$ as described in the Japanese Pharmacopocia (JP XII). The liposomes were then collected by filtration and washed with distilled water. The collected liposomes were dissolved completely in phosphate buffer $(\mathrm{pH} 7.5)$ and assayed for the denazyme AP activity that was retained after treatment with the acidic solution. The resistance of the denazyme AP was expressed as the percentage of initial denazyme AP activity retained.

The release of denazyme AP from the liposomes was evaluated as follows. A $100 \mathrm{mg}$ aliquot of the liposomes was incubated at $37^{\circ} \mathrm{C}$ with reciprocal shaking (100 strokes/min) in $15 \mathrm{ml}$ of phosphate buffer ( $\mathrm{pH} \mathrm{6.8)} \mathrm{described} \mathrm{in} \mathrm{JP} \mathrm{XII.} \mathrm{At} \mathrm{appropriate} \mathrm{times,} \mathrm{the}$ solution was filtered, and the activity of denazyme AP in the filtrate was assayed.

\section{Effect of bile salts on release of denazyme AP from liposomes}

A solution of bile acids simulating human intestinal content was prepared in the manner described by Hofmann (1963). Twenty mM solutions of each of the six bile salts were prepared in phosphate-buffered saline $(\mathrm{pH} \mathrm{6.2)}$ and were then mixed in the following manner (by volume): sodium glycocholate, $30 \%$; sodium glycochenodeoxycholate, 30\%; sodium glycodeoxycholate, $15 \%$; sodium taurocholate, $10 \%$; sodium taurochenodeoxycholate, $10 \%$; sodium taurodcoxycholatc, $5 \%$. This solution was then mixed 1:1 with liposomes to give a final concentration of $10 \mathrm{mM}$ bile salts. The liposomes were incubated at $37^{\circ} \mathrm{C}$ in $10 \mathrm{mM}$ bile salts at $\mathrm{pH} 6.2$. At appropriate intervals, the solution was filtered, and denazyme AP activity in the filtrate was assayed.

\section{RESULTS AND DISCUSSION}

\section{Efficiency of encapsulation and morphology of liposomes}

First, we investigated the efficiency of encapsulation of denazyme AP into liposomes. As shown in Table 1, we found that REV method generated liposomes with a yield of $52.0 \%$. This suggests that liposomes formed by this technique, which are referred to as 
reversc-phase evaporation vesicles, have a high aqucous space-to-lipid ratio and encapsulate a high percentage of the initial aqueous phase. On the other hand, the encapsulation efficiency of liposome-capsule by the EI method was 26.5\%. However, because encapsulation efficiencies of such methods as vortex (Bangham el al., 1965), sorication (Kirby ot $a l ., 1980$ ), and detergent-removal (Zumbuchl et al., 1981) are $5 \%$ at the most, we assumed that liposome-encapsulation techniques by the REV method and the EI mothod were both effective and economical and convenient enough to be suitable for the food industry.

Figure 1 shows a photomicrograph of liposomes prepared by the REV method. Liposome unilamellar lipid vesicles with a particle diameter of several $\mu \mathrm{m}$ can be seen. The liposomes are miniscule, homogeneous particles that would have little effect on the quality of the original foods to which they have been added.

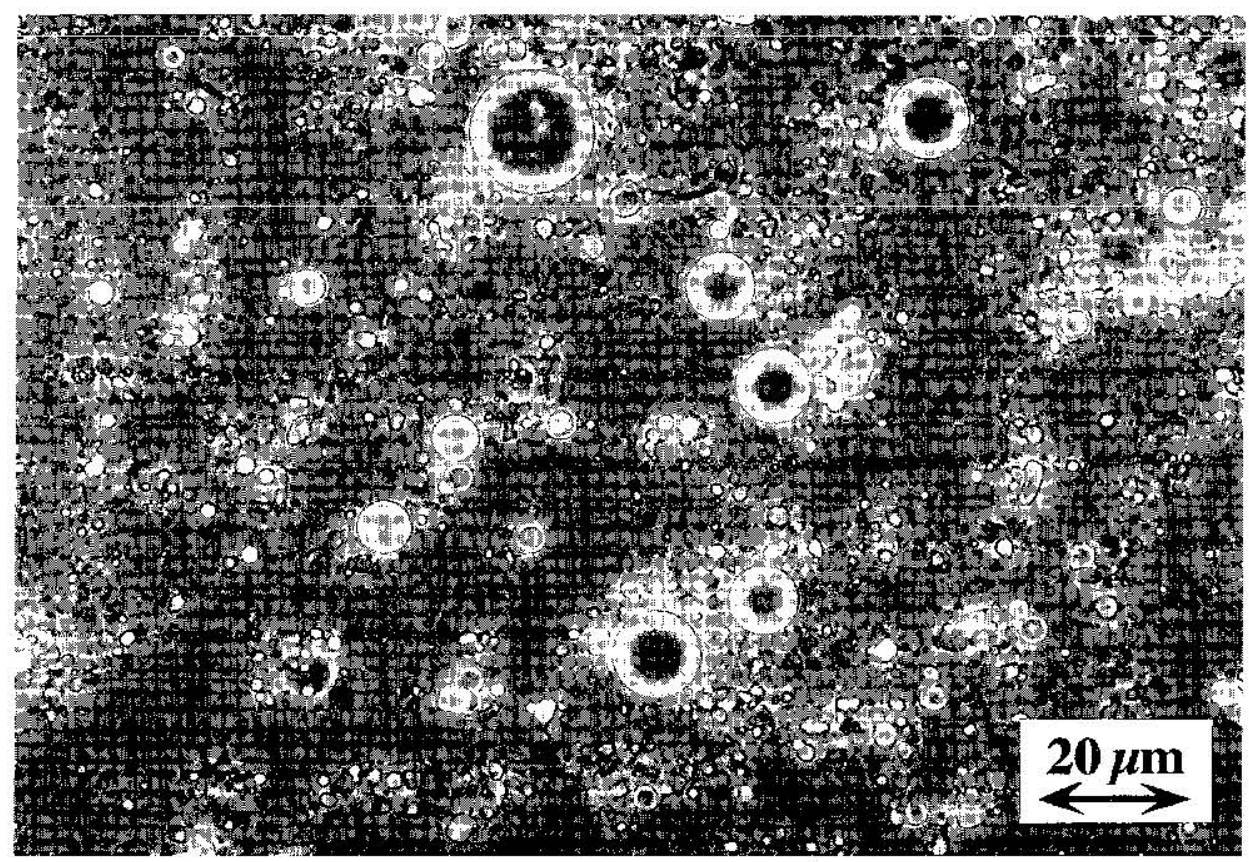

Fig. 1. Photomicrograph of liposomes prepared by the REV method. 
Table 1. Encapsulation Efficiency of Denazyme AP inlo Liposomes.

\begin{tabular}{|c|c|c|}
\hline Liposomes & $\begin{array}{l}\text { Deriazyme AP activity } \\
\text { (U) }\end{array}$ & $\begin{array}{l}\text { Trap ratio } \\
(\%)\end{array}$ \\
\hline Start & 43060 & 100.0 \\
\hline EI method" & 11411 & 26.5 \\
\hline REV method & 22391 & 52.0 \\
\hline \multicolumn{3}{|c|}{$\begin{array}{l}\text { One unit was defined as the enzymatic activity that liberated } \\
\text { rolin-positive amino acids and pcptides cquivalent to } 1 \\
\mu \lambda \mathrm{mol} / \mathrm{min} \text { of tyrosine. } \\
\text { "EI method=ethanol injection method. } \\
\text { "REV method=reverse--phase evaporation vesicle method. }\end{array}$} \\
\hline
\end{tabular}

\section{Resistance of liposomes to degradation in the gastric environment}

To investigate the resistance of liposomes to degradation in the gastric environment, liposomes prepared by the REV method and the EI method were treated with a gastric solution ( $\mathrm{pH} 1.2, \mathrm{HCl}$ solution containing $0.2 \% \mathrm{NaCl}$ ), and the enzymatic activity of denazyme AP encapsulated in the liposomes was measured. Denazyme AP activity inside liposomes produced by the REV method was barely affected by the gastric solution during a 6-hr incubation, while the protective effect of the liposomes produced by the EI method was slightly lower. On the other hand, Shimizu et al. (1993) reported that liposomal membrane prepared from egg yolk lecithin was almost completely stable against digestion by pepsin. These results demonstrate that the liposome-encapsulation by these methods is an effective means for protecting orally administered inclusion substances from gastric conditions and that the liposome preparations have the potential to pass through the stomach without a great loss of activity within its residence time (about $6 \mathrm{hr}$, Muto, 1990).

\section{Release of liposomes in the intestinal tract}

These liposomes must disintegrate in the intestinal tract after passage through the stomach to release denazyme AP from the liposomes. We next examined the release of denazyme AP from the REV-and the EI-liposomes in intestinal fluid ( $\mathrm{pH} 6.8$, phosphate buffer). No permeation of denazyme AP through the liposomal membrane was observed in either liposome capsule, even after incubation for $3 \mathrm{hr}$. This deficiency of disintegration was thought to be due to the extremely high stability of egg lecithin used.

To improve the disintegration of liposomes, we investigated the efficiency of release of the liposomes in a solution of bile salt responsible for digestion and absorption of lipids (Rowland and Woodley, 1980; Nagata et al., 1990). As shown in Fig. 2, little release of denazyme AP from liposomes prepared by the EI method was observed for up to $3 \mathrm{hr}$ under a similar conditions as in intestinal fluid. By contrast, about $80 \%$ of denazyme AP 
was released within only $10 \mathrm{~min}$ and more than $90 \%$ was released within $3 \mathrm{hr}$, when liposomes produced by the REV method were incubated with a solution of bile salts. This finding suggests that liposomes produced by the REV method have the potential to release inclusion substances within their residence time in the bile salt-rich intestinal tract. Therefore, we concluded that these liposomes permitted passage of the inclusion substance through the gastric tract with little degradation and offered the subsequent release of the inclusion substance in the intestinal tract.

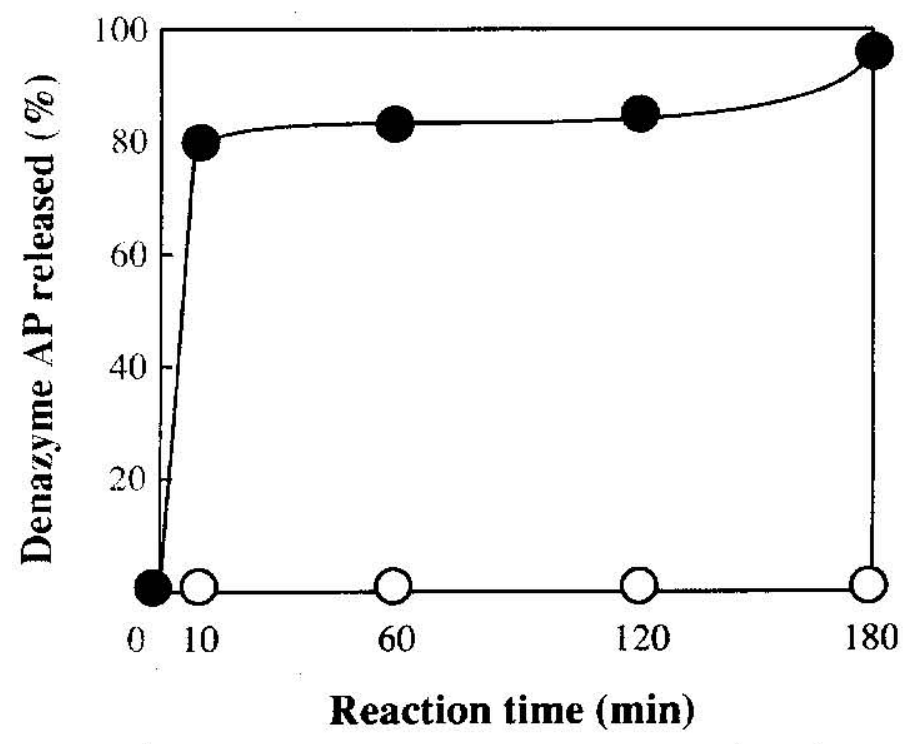

Fig. 2. Release of denazyme AP from liposome-capsules in a $10 \mathrm{mM}$ solution of bile salt at $37^{\circ} \mathrm{C}$; reverse-phase evaporation vesicle method (O); ethanol injection method ( $O$ ).

\section{Effect of lecithin concentration and the ratio of lecithin/denazyme AP on the encapsulation of denazyme AP in liposomes}

As described above, it became clear that a REV method was effective for preparing liposomes with release efficiency of denazyme AP in the intestinal tract. Considering its possible wide application in the food industry, it seems desirable to increase the quantity of denazyme $\mathrm{AP}$ encapsulated by this method. We investigated the optimal conditions to maximize efficiency of liposome encapsulation. Figure 3 shows the effect of lecithin concentration on the encapsulation of denazyme AP. By increasing the lecithin content from 25 to $75 \mathrm{mM}$, the quantity of encapsulated denazyme AP was almost doubled. The 
increment then leveled off, and the encapsulation efficiency held constant. This increment of encapsulation efficiency occurs because at the point of removal of the organic phase, some of the phospholipid monolayer, which is produced by the initial sonication treatment, disintegrates, releasing its encapsulated denazyme AP; then the excess lecithin contributes to formation of a complete bilayer around the remaining monolayer-liposomes and denazyme AP. Moreover, when each liposomes prepared with various lecithin concentrations was incubated with a solution of bile salt, release of the liposomes was almost identical up to $75 \mathrm{mM}$ lecithin concentration, showing efficiency of release of about $80 \%$ within $1 \mathrm{hr}$.

The effect of the egg lecithin/denazyme AP ratio on the encapsulation efficiency of denazyme AP is shown in Figure 4. By slightly increasing the amount of denazyme AP, the efficiency was markedly increased. However, the efficiency decreased again when the denazyme AP was increased to 1.0 or higher.

In summary, we concluded that the REV method with a $75 \mathrm{mM}$ lecithin concentration and a lecithin/denazyme AP ratio of 1.0 was an effective liposome-encapsulation technique with high encapsulation efficiency. This relatively simple technique has unique advantages for encapsulation of valuable water-solublc matcrials such as proteins, drugs, and other biochemical reagents for oral administration.

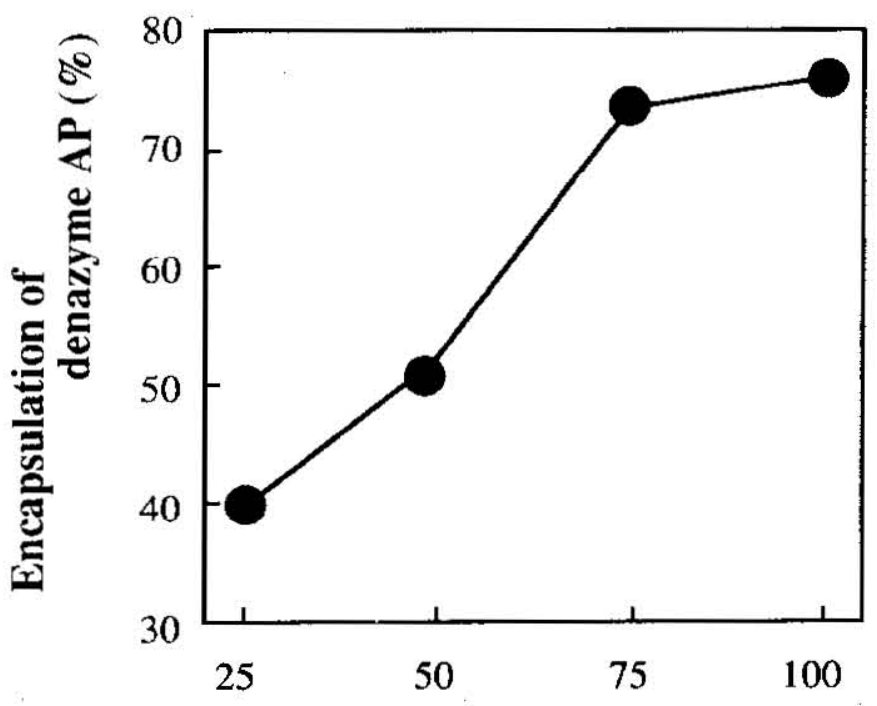

\section{Lecithin concentration ( $\mathrm{mM} / \mathrm{ethanol}$ )}

Fig. 3. Effect of lecithir concentration on the encapsulation efficiency of denazyme AP. 


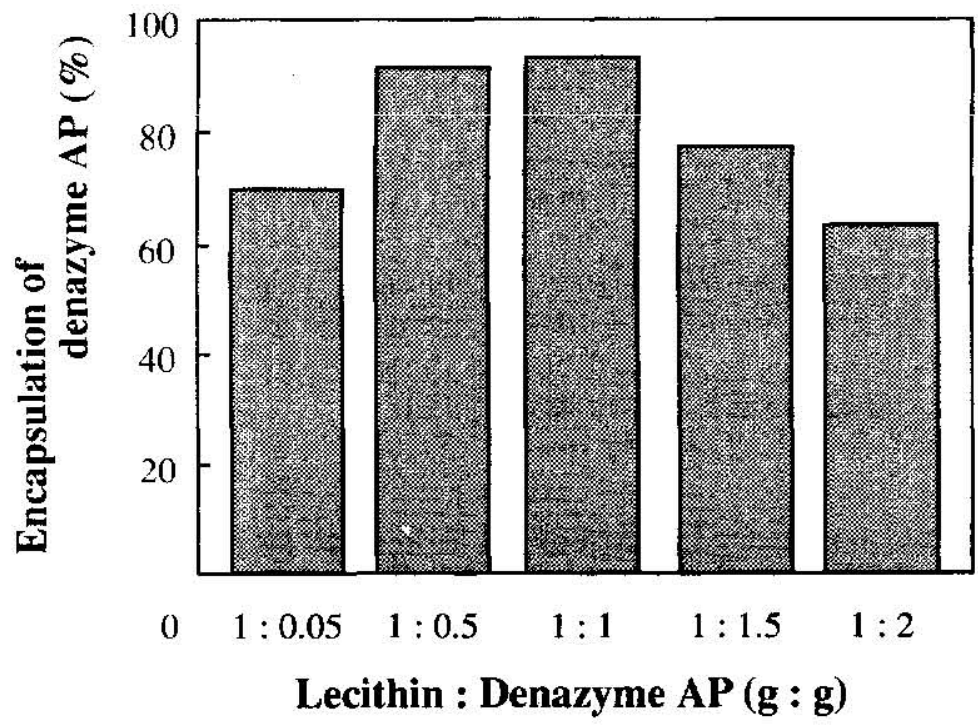

Fig. 4. Encapsulation of denazyme AP in liposomes of different egg lecithin/denazyme AP ratios. The amount of total lipid was $1.5 \mathrm{~g}$.

\section{REFERENCES}

Anson, M. L. 1938 The estimation of pepsin, trypsin, papain, and cathepsin with hemoglobin. J. Gen. Physiol, 22: 79-89

Bangham, A. D., M. M. Standish and J. C. Watkins 1965 Diffusion of urivalent ions across the lamellae of swollen phospholipids. J. Mol. Biol, 13: 238-252

Hofmann, A. F. 1963 The function of bile salts in fat absorption. Biochem. J., 89: 57-68

Kirby, C., J. Clarke and G. Gregoriadis 1980 Effect of the cholesterol content of small unilamellar liposomes on their stability in vitro and in vivo. Biochem. J., 186: 591-598

Muto, Y. 1990 Shoka $\cdot$ Kyushu. Daiichi Shuppan, Tokyo (Japan), pp. 119-187

Nagata, M., T. Yotsuyanagi and K. Ikeda 1990 Bile salt-induced disintegration of egg phosphatidylcholine liposomes: A kinetic study based on turbidity changes. Chem. Pharm. Bull., 38: 1341-1344

Patel, H. M. and B. E. Ryman 1976 Oral administration in insulin by encapsulation within liposomes. FEBS Lett., 62: 60-63

Rowland, R. N. and J. F. Woodiey 1980 The stability of liposomes in vitro to pH, bile salts and pancreatic lipase. Biochim. Biophys. Acta, 620: 400-409

Rowland, R. N. and J. F. Woodley 1981 Uptake of free and liposome-entrapped horseradish peroxidase by rat intestinal sacs in vitro. FEBS Lett., 123: 41-44

Shimizu, M., Y. Miwa, K. Hashimoto and A. Goto 1993 Encapsulation of chicken egg yolk immunoglobulin G (IgY) by liposomes. Biosci. Biotech. Biochem., 57: 1445-1449 
Zumbuehl, O. and H. G. Weder 1981 liposomes of controllable size in the range of 40 to 180 num by defined dialysis of lipid/detergent mixed nicelles. Biochim. Biophys. Acta, 640:252.262 